\title{
A PROTEÇÃO EXCESSIVA NA LEI DE SOFTWARE, SEU IMPACTO NO DESENVOLVIMENTO DA INFORMÁTICA NO BRASIL E A PROPOSTA DE UMA REDUÇÃO DO TEMPO DE TUTELA.
}

\author{
Matheus Henrique Pereira ${ }^{1}$ \\ Mauricio M. Alves²
}

Resumo: O artigo defende que há uma proteção excessiva na tutela da propriedade intelectual de programa de computador (software) no artigo $2^{\circ}$ da lei 9609/98-conhecida como "lei de software"- o que acaba por atrasar o desenvolvimento e crescimento da área e afins; mostra também o embate entre "direito de propriedade" e "função social da propriedade" presente no tema e propõe, como uma possível ação para reduzir este problema, uma redução do tempo de tutela concedida aos softwares pelo Estado brasileiro, de forma que tanto o direito de propriedade, quanto a função social da propriedade sejam respeitados.

Palavras-chave: Direito, informática, análise, software, tutela.

\footnotetext{
${ }^{1}$ Univap/Faculdade de Direito, Brasil. E-mail: matheus.pereira78@etec.sp.gov.br.

2 Univap/Faculdade de Direito, Brasil. E-mail: mmalves@univap.br.
} 